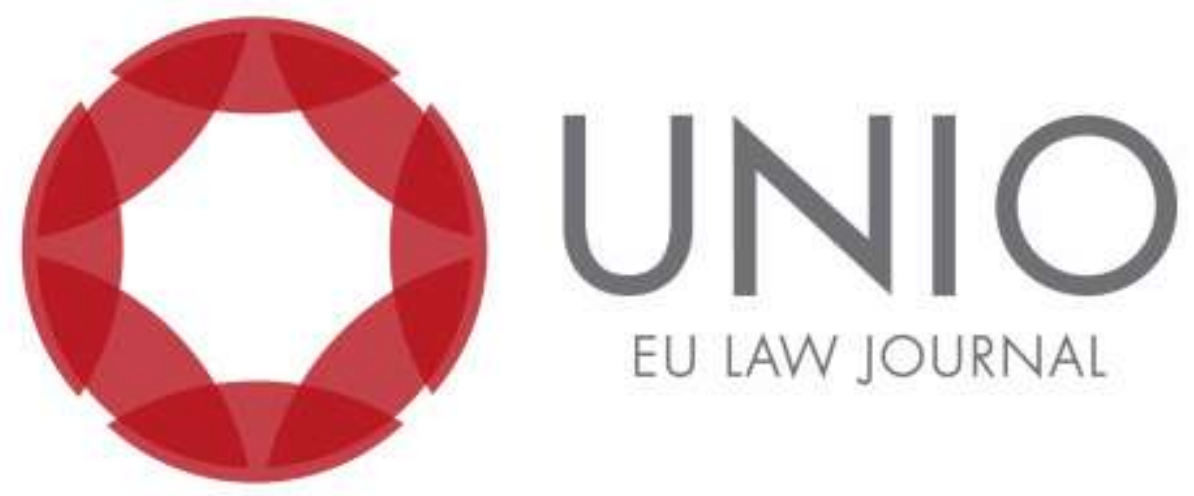

\title{
Union citizenship as an instrument for the protection of rights and means of fostering cohesion among European citizens
}

\section{Maria Rosa Oliveira Tching}

\section{Judge at the Court of Appeal of Guimarães}

ABSTRACT: In a European Union still ridden with social and economic imbalances, the author calls for greater convergence between citizenship and fundamental rights in order to make the European citizen a more complete being, enjoying rights resulting from the European citizenship status, including the rights enshrined in Article 20 of the Treaty on the Functioning of the European Union (non-discrimination, freedom of movement, residence, political and civic participation, diplomatic protection) and the rights listed in the Charter of Fundamental Rights of the European Union and the European Convention on Human Rights and Fundamental Freedoms. The author emphasizes the importance of the European citizenship status as an instrument of protection of rights and an element of cohesion among Union citizens - and, in this context, highlights the case law of the honoree Judge Cunha Rodrigues as a precursor to a new dimension of Union citizenship and the consequent widening of the scope of European Union law.

KEYWORDS: European citizenship - fundamental rights - protection of rights cohesion between Union citizens - Cunha Rodrigues.

It is with great joy that I return to this school, which is also my own.

I would like to begin by thanking Professor Alessandra Silveira and the School of Law of the University of Minho, represented here by its President, Professor Mario Monte, 
for the invitation to be part of this colloquium. I am most honoured to be here paying tribute to Judge Cunha Rodrigues.

It is not an easy task paying tribute to such a reputed magistrate due to the greatness and notability of his work throughout his entire career. I believe, however, that the best way to honour you, Sir, is by leaving aside big words and to speak from the heart. Therefore, I would like to tell you that I became a judge by having you as a reference and by trying to follow the seven commandments that you proposed for justice: «lightness, visibility, communication, speed, accuracy, multiplicity and consistency». ${ }^{1}$ I have always admired your ethical rigour, your intellectual brilliance and your total dedication to the judiciary and to the causes of Law and Justice. From you, I have drawn great lessons. To be a judge is also «to pay attention to the great social aspirations while being faithful to the Law and legal values»; «to cultivate the interior as a professional dimension». ${ }^{2}$ In my eyes, it is precisely the greatness of your humanity that makes you, Sir, someone with a «fragrant soul» as the poet Carlos Drumond de Andrade would say.

Indeed, knowing the procedural deficit in the protection of individual rights, in the current framework of the European judicial system, only the bravest spirits and those most sensitive to the human and social dimension of the European citizen were able to, in a still fairly unequal European Union in social and economical terms, to bring citizenship and fundamental rights closer together, rendering the European citizen a more complete being, a holder of fundamental rights protected by the European legal order.

This was precisely the line of reasoning expressed by Judge Cunha Rodrigues in the Judgment of the Grand Chamber on the Michel Trojani case, in which he acted as rapporteur, ${ }^{3}$ by recognizing to a French citizen, legally residing in Belgium (as he held a residence card issued by the competent Belgian authorities), who was unemployed and suffering from financial difficulties, the possibility to invoke the current Article 18 TFEU and based on it to demand that the Belgian national authorities respect the

\footnotetext{
${ }^{1}$ Cunha Rodrigues, Recado a Penélope, (Lisboa: Sextante Editora, 2009), 81.

${ }^{2}$ Cunha Rodrigues, Recado a Penélope, 34.

${ }^{3}$ Cf. Judgment Michel Trojani, 7 September 2004, Case C-456/02.
} 
principle of non-discrimination based on nationality in the right to benefit from social assistance, such as «minimex».

And by stating that, even in the hypotheses of the host Member State considering that a national from another Member State which turned to social assistance, stopped fulfilling the requirements on which his right of residence depends of and opts for a removal order, the right to residence of Michel Trojani will always have its basis on the Union citizenship status, under the now Article 21 TFEU.

Therefore and insofar as it recognises that an economically inactive Union citizen, based solely on his status as a European citizen, may benefit from the fundamental principle of equal treatment and exercise his right of residence in direct application of the now article 21 TFEU, this judgment constitutes an important step forward in the densification of the rights associated to the Union citizen status.

This is made possible, not only by rendering the principle of non-discrimination legally binding within the Union and by transforming it into a fundamental and individual right of European citizens, regardless of differing nationalities, but also by separating the said right of residence from strictly economic factors connected to the free movement of productive factors.

Another case worth mentioning, due to the ingenuity with which its rapporteur, Judge Cunha Rodrigues, combined citizenship and fundamental rights in order to protect the family life of the European citizen and her ascendants, who are third country nationals, is the Judgment Zhu and Chen ${ }^{4}$.

This case concerned a minor, who was the daughter of Chinese nationals, who acquired Irish nationality simply because she was born in Northern Ireland, but not the British nationality because the United Kingdom adopted the «jus sanguinis» criterion together with the «jus soli» criterion. Given that the refusal of the United Kingdom authorities to grant a residence permit to the mother and daughter was based on the grounds that the latter never exercised any of the rights provided for in the Treaty, the question at hand

\footnotetext{
${ }^{4}$ Cf. Judgment Zhu e Chen, 19 October 2004, Case C-200/02.
} 
was whether the minor, Catherine Zhu, as a European Union citizen, had the right to enter and reside in the United Kingdom and whether that right also extended to Mrs Chen, her mother, seeing as she had the minor in her custody.

Broadly speaking, the Court of Justice concluded that, as a Union citizen, Catherine had the right to invoke the now Article 21 TFEU and that this article as well as Directive 2004/38/EC (given that it was not required that the minor herself had the necessary economic resources), granted her the right to reside for an indefinite period in the territory of the host Member State. The Court also granted the same right to her mother, for, as it was previously ruled in the Judgment Baumbast, the enjoyment of the right of residence by a young child implies that the child is entitled to be accompanied by the person who is his or her primary carer. All without the need to invoke the right of a child to live as part of a family in Article 8 of the European Convention on Human Rights or the right to non-discrimination in Article 14 of the same convention.

Worthy of greater consideration, for going even further in the protection of the rights of children born in the territory of a European Union Member State and for ruling out the requirement derived from the Judgment Chen, the one which requiring the parents, as citizens of third countries, to demonstrate the sufficiency of economic resources to support their families, is the Judgement Ruiz Zambrano, ${ }^{5}$ in which Judge Cunha Rodrigues also acted as rapporteur.

This Judgment is a truly historical milestone in the case law of the Court of Justice, insofar as it is an important step in regards to the impact of fundamental rights in determining the scope of application of European citizenship. Ruiz Zambrano and his wife, both Colombian nationals, entered Belgium with a visa issued by the Belgian authorities in Bogotá with the objective of seeking asylum there. The Belgian authorities denied the asylum request but did not repatriate them given the ongoing civil war in Colombia. The couple submitted several applications for residence permits, which were systematically rejected, and ultimately, the work permit was also rejected.

\footnotetext{
${ }^{5}$ Cf. Judgment Ruiz Zambrano, 8 March 2011, Case C-34/09.
} 
Meanwhile, the couple had two sons who acquired Belgian nationality. The Court of Justice, recognizing that Directive 2004/38 only applies to Union citizens «who move to or reside in a Member State other than that of which they are a national, and to their family members», found that it did not apply to this case. Afterwards, despite granting that there was no exercise of freedom of movement, the Court reiterated, according to the Grzelczk, Baumbast, Garcia Avello, Zhu and Chen, and Rottmann case law, that Article 20 (1) TFEU grants to all nationals of a Member State the Union citizen status, precluding national measures which deprive citizens from the full enjoyment of the rights granted by this status.

The Court recognized that the refusal of residence to the parent, a third country national, in the Member State of which his or her young children are nationals and where they reside, would result in the departure of the children from the Union territory to follow their parents. Additionally acknowledging that the refusal of a work permit would have identical consequences, since the parents would be at risk of not being able to provide for themselves and their family, the Court concluded that these decisions were incompatible with Article 20 TFEU, for the said children would not be able to exercise the rights conferred by their status as Union citizens.

In light of this, the right of a child to live and reside in the territory of a Member State, provided that it derives from his or her European citizenship status, is sufficient in and of itself to guarantee the right of residence for his or her parents as well as the permit for them to work in order to allow their social integration in that State, providing that the parents have his or her custody.

It should be noted that the Court of Justice's acceptance of the reasoning presented by Ruiz Zambrano and the Advocate General concerning the autonomous nature of the right of residence provided for in Article 21 TFEU, has significant consequences, to the extent that it ended the difference of treatment between dynamic and static citizens. It is also possible to conclude that the Court of Justice dismisses the qualification of a situation as purely internal when the national measure has the effect of depriving a Union citizen from the effective enjoyment of the rights associated to his or her status, even when the right to free movement is not exercised. This implies, to a degree, a significant enlargement of the scope of application of European Union law. 
Based on this Judgment, it can thus be concluded, on one hand, that invoking European citizenship provisions (Article 20 TFEU) does not depend on the previous exercise of the right to free movement. And, on the other hand, it can also be concluded that through European citizenship, one can gain access to the European standard of protection of fundamental rights, since, at heart, the Zambrano case is also a case about the protection of the fundamental right to respect for family life provided for in Article 7 CFREU. All of this means that movement is no longer necessary for the application of the provisions in the TFEU concerning citizenship, ensuring that dynamic and static citizens may invoke the European standard for protection of fundamental rights through the European citizenship status.

For the protection of fundamental rights and whenever the essential enjoyment of such rights is at risk, this status will be, in and of itself, sufficient, to establish the connection between the situations provided for in Union law. The Union citizenship status now has a main role as a primary source of the rights and duties granted to Union citizens and their closest relatives and also as an instrument for the protection of citizenship rights and other fundamental rights protected by the European legal order such as the ones provided for in the Charter of Fundamental Rights of the European Union and in the European Convention on Human Rights, and also as an element of cohesion among Union citizens. This reveals, in the words of José Renato Gonçalves, ${ }^{6}$ a new dimension of the Union citizenship, one which concerns the protection of the Union citizens' rights as real European citizens, with a connection to the territory ${ }^{7}$ and to the values of the European Union, not just to its Member States, therefore going beyond the national idea of protection of individual rights against potential acts of discrimination by the national authorities.

Thus, looking at the current state of the Court of Justice case law, we can claim that, in spite of the difficulties encountered in the determination of the scope of the criteria established in the Judgment Zambrano and the uncertainties concerning the definition

\footnotetext{
${ }^{6}$ Cf. José Renato Gonçalves, in Jurisprudência Cunha Rodrigues - Comentários, ed. Eduardo Paz Ferreira, Maria Luísa Duarte, Miguel Sousa Ferro, (Lisboa: Associação Académica da Faculdade de Direito de Lisboa, 2013), 74.

${ }^{7}$ Which, in his own words, more than the sum of the several physical territories of the Member States, that territory correspond to a common space of rights and values defined by European Union law. Cf. José Renato Gonçalves, in Jurisprudência Cunha Rodrigues - Comentários, 71.
} 
of the citizenship concept in times of profound economic and social crisis, solving the citizenship puzzle will depend on how the Court of Justice will in the future, interpret the concept of «fundamental rights essence» associated with the European citizenship status. On this subject, in light of the level of fundamental rights protection already achieved in the European Union, one in which Judge Cunha Rodrigues played an active role of particular importance, looking at the future, we believe that there is no reason to fear a restrictive interpretation of that concept.

We even dare to foresee that it will actually be subject to an increasingly wider interpretation for this was the harbinger indicated by the Court of Justice by holding, in the Judgment Grzelczyk ${ }^{8}$ that «Union citizenship is destined to be the fundamental status of nationals of the Member States, enabling those who find themselves in the same situation to enjoy the same treatment in law irrespective of their nationality, subject to such exceptions as are expressly provided for».

Thank you, Judge Cunha Rodrigues, for your enormous contribution in the field of the European Union citizenship and Fundamental Rights.

Thank you all for your attention.

\footnotetext{
${ }^{8}$ Cf. Judgment Grzelczyk, 20 September 2001, Case C-184/99.
} 